\title{
The Analysis of Market Power and Bank Soundness on Islamic and non-Islamic Bank Behavior
}

\author{
Raihan Mahendra $^{1 *}$, M. Budi Prasetyo ${ }^{1}$ \\ ${ }^{1}$ Faculty of Economics and Business, Universitas Indonesia \\ Email: raihan.mahendra@ui.ac.id
}

\begin{abstract}
The objective of this research is to determine the effect of bank market power and bank soundness on the behavior of Islamic and non-Islamic bank to collect and channel public funds during periods of 2011-2015. Using Lerner Index to measure bank degree of market power, and CAR as a measure of bank soundness, the result on Islamic bank showed a significant positive relationship only on bank channeling of funds. However, on non-Islamic bank the result showed a significant positive relationship on bank collecting and channeling of funds. Bank collection and channeling of fund will be greater on when bank market power and bank level of soundness also rises.
\end{abstract}

Type of Paper: Empirical

Keywords: Lerner Index; Bank Market Power; CAR; Commercial Bank behavior

\section{Introduction}

Financial institutions play a huge part to encourage economic development within a country, without exception the shari'ah economy. In Indonesia, banking institution still dominating the financial industry/ According to Bank Indonesia, at the end of 2016, bank dominate $74.93 \%$ share of financial institution assets compared to other non-bank financial institutions. Moreover, Bank Indonesia also mentions that the banking industry is still relatively strong and will continue to grow in line with the continued growth of banking assets and third party funds collected by bank. As one of the financial institutions, Bank has a primary duty to act as the financial intermediary which connects the parties who have funds and want to invest it to the parties who in need of funds. Bank activities in channeling excess of fund to borrowers create the opportunity to invest on productive sector especially if the financing is not used for consumptive purposes. Such financial activities are essential to ensure that the financial system and the economy run smoothly efficiently.

Pepall (2005) states that the relationship between economic structure, corporate behavior and economic performance can be described through the SCP (structure-conduct-performance) paradigm. For example, the behavior of companies in an industry will affect the equilibrium 
price and the total output produced in the industry so that it will directly affect the people's welfare. Allen and Gale (2004) mentioned that risk-taking behavior and determining the amount of credit disbursed on a bank will depend on the level of competitiveness in the banking industry. Using dynamic optimization model, Suarez (1994) shows in his research that there is a tradeoff between market power and bank solvency. If the market power of the bank decreases, it should encourage the bank to carry out prudent policies that increase the solvency of the bank. Matutes and Vives (2000) shows that on the perfect competition market, increase on market power will decrease bank probability of default.

Market power serves as a tool for measuring company's ability to raise price levels above its own marginal cost (Church and Ware, 2000). It also serves as benchmarks for the level of competition in an industry, which has become the focus in any industrial economic study, especially regarding the banking industry. A high market power value means that the company has a monopoly power or in the other word the industry is a monopoly market. Competition in the banking industry keeps increasing, and this is due to several factors such as market expansion by foreign financial institutions and/or a new financial products and services offered by company to compete for market share. Competition is often to blame for encourage banks to try and do anything to reach maximum profit including high-risk action that often may lead to a financial crisis.

Previous research about the level of competition on shari'ah bank and conventional bank lead to various results. Ariss (2010) argues that shari'ah banks have a greater market power compared to conventional banks. Louati et al (2015) adds that the level of competition on shari'ah banks will have no significant effect to the growth in bank financing. Similarly, Weill (2011) find that there were no significant differences in the level of competition between shari' ah banks and conventional banks. Based on previous research, it can be concluded that the market structure (described and measured with market power) proved to have a significant influence on corporate behavior. In addition, most of previous research only focused on conventional banks in developed countries. Therefore, to fill the research gap, this paper will see whether the same relationship will also occur if the research is conducted using a sample bank in developing countries and samples of shari'ah banks that have different operational characteristics with conventional banks.

The objective of this research is to find out the level of competition and market power of banking industry in Indonesia using Lerner index as a direct measure for bank market power. In addition, this research also aim to determine whether the CAR and the level of competition in the banking industry has a significant role in the growth of credit and deposits of Islamic banks and conventional. Given the limited amount of literature references available on the comparison of banking capital structure and market power among shari'ah banks and conventional banks in Indonesia, this research could give a major contribution as a literature reference by underlining the influence of market power and bank soundness on the bank behavior in channeling and collecting public funds.

This research used only a commercial bank in Indonesia as a sample due to several reasons. First, Indonesia is a country with the largest Muslim population in the world. Second, the development of shari'ah banks in Indonesia is driven by the demand of the consumers, different from government-initiated shari'ah bank such as Malaysia. Lastly, Indonesia has experienced several financial crises that bring significant impact on its financial stability. Based on the 
above reasons, the banking market in Indonesia has unique characteristics compared to other countries, which make it necessary to do a research to properly described the bank's behavior in Indonesia

The research is divided into several sections as follows. Section 1 introduces the research. Section 2 explores the literature that addresses the theoretical basis of research topics. Section 3 presents the methodology that consist of research methods and materials. Section 4 discussion and analysis of the results and findings. Section 5 concludes the findings that found on Section 4.

\section{Literature Review}

\subsection{Shari'ah Banking}

The development of shari'ah financial services worldwide is growing rapidly. Notwithstanding the fact that most countries in the world have not yet specifically supported the usury free economy, the IMF data shows that the shari'ah economy experienced a growth of $15-20 \%$ per year. In addition, Abduh and Omar (2012) mention that Islamic banking assets are expected to continue to grow at a rate of $15 \%$ per year worldwide. This certainly attracts the attention of all countries in the world to create an Islamic economic system, especially given its free of crises nature.

According to Ayub (2007), shari'ah bank is an intermediary financial institution that perform its activities in accordance with the principles of shari'ah by avoiding activities that contain elements of usury, uncertainty, and gambling. Furthermore, Islam does not recognize debt or commercial loans but in the form of partnership or cooperation (Mudaraba and Musharaka) with the principle of profit and loss sharing. While lending money to others is only possible for social purposes without any reward or better known as Qardh (Antonio, 2001). The prohibition of usury in shari'ah bank is the main point because as we know, conventional bank depends on interest as a return of investment. Interest arises as a compensation for loss caused by time value of money or remuneration received on the customer's willingness to deposit funds in the bank. Ayub (2007) mentions that prohibition of usury makes shari'ah bank will not provide loans for making profit in the form of interest. Channeling of funds by shari'ah bank will take form of investments that involve not only the transfer of funds but also require risk sharing as a form of partnership.

Chong and Ming-Hua (2009) mention that investor have the obligation to bear risk together with the borrower. Since both the borrower and investor have no power and cannot be blamed for the risk of loss in business, both parties are equally obliged to bear the loss and share the profits. To do so, shari'ah bank applies a profit-loss sharing scheme in all its products. The fixed rate in the form of interest rate will be replaced by the pre-determined ratio of profit-loss sharing between both parties. While in terms of fund raising, the application of wadiah based contract means that the bank has the obligation to keep the value of saving account, but on the other hand the bank also has no obligation to provide profit sharing funds to the customer. Meanwhile, the application of PLS scheme on fund raising such as mudaraba and musharaka contract require the losses incurred on investment are borne by investor solely, but bank is obliged to set aside some of its profits as a profit shared to the investor. 


\subsection{The Impact of Market Power and CAR}

Structure conduct performance (SCP) theory believes that market structure will affect the performance of an industry. This theory is based on assumption that the market structure will affect the behavior of companies that will ultimately affect the performance of companies and industries in aggregate as revealed by Pepall (2005). From a business competition point of view, a concentrated market tends to potentially lead to a variety of illegal unfair business behavior to maximize profit $(\mathrm{P}>\mathrm{MC})$ due to market power.

The analysis of market structure has become the focus in the industrial economic studies, including assessments of the level of competition and market power in the banking industry. As a financial intermediary between a surplus spending unit and a party requiring funds, banking institution has a vital role in supporting economic development process. Martinez and Repullo (2010) explain that increased competition will indeed lower interest rate of credit, but a decrease in interest rate will prompt bank to increase financing and further increase bank risk of failures. While Yevati and micco (2007) found that increasing bank competition will increase the bank tendency to take risks as illustrated by the growth of bank financing in eight Latin American countries.

In addition to market power, bank soundness and capital strength of a bank will also affect bank behavior (Mastura et al, 2014). Mastura et al (2014) argue that CAR (Capital Adequacy Ratio) is considered by most people causing a declining commercial bank loan growth. Minimum capital restrictions make banks forced to hold a certain amount of capital and reduce credit offerings to maintain its CAR above the required minimum ratio, which then will have an impact on bank performance and profitability of banks. To comply with capital requirements, banks must choose between raise its capital; reduce asset portfolios; or invest in more low risk investments.

\section{Research Methodology}

This paper will use secondary data in the form of bank financial statements sourced from the Indonesian banking directory by OJK and Bank Indonesia. The number of banks used as sample in this research are 69 conventional banks. In addition, there are 19 Islamic banks consisting of 13 shari'ah banks (BUS) and six shari'ah business unit (UUS). Local government bank (BPD) were not included in the sample because BPD have a limited market area on certain province so it is not competing in the same market (national scale) with other research samples. Furthermore, in practice, BPD performance is highly dependent on the behavior of its local government so. For example, Bank Maluku Utara on 2016 recorded a decrease on liability caused by decreased Giro Local Government sequestered in the financing of projects and recurrent expenditure of Local Government at the end of the year. This indicates that BPD still depends greatly to its own local authorities.

The research period of this study is the year of 2011-2015. The period was chosen because data over 5-year period is considered to have well-described panel data and the researchers seek to use the latest data possible to illustrate the current state of the banking industry that takes place. Moreover, the banking industry during this period was relatively stable and did not have significant problems that interfere with the analysis of the hypothesis. Prior to 2008, there was a Century case that was likely to have significant influence on banking behavior and 
banking system stability. Since our study include both the time and the individual dimensions, the estimation method based on econometric panel data seems to be the most appropriate. The panel estimation method helps multiply the number of observations and study both spatial and temporal trends. We conducted a Hausman test for each regression to determine if it is a fixed or random effect.

\subsection{Research Model}

The research model used in this paper is a model of research conducted by Louati et al (2015) that modified previous research by Mastura et al (2014). Louati et al (2015) looks at the influence of market power and CAR of shari'ah bank and conventional bank in influencing the bank's behavior in channeling and collecting funds. To measure market power, Louati et al (2015) uses the non-structural method of the Lerner index to directly know the bank market power, while measuring CAR using measurement methods through risk-weighted assets listed in Basel risk management. Following Louati et al (2015), then in general this study will use the following regression model estimation

$$
\begin{gathered}
Y_{i t}=\alpha_{0}+\beta_{1} \text { Lerner }_{i t}+\beta_{2} \text { CAR }_{i t-1}+\beta_{3} \text { Size }_{i t-1}+\beta_{4} E Q_{i t-1}+\beta_{5} L Q_{i t-1}+ \\
\beta_{6} \text { Fee }_{i t-1}+\beta_{7} \text { Inflasi }_{t}+\beta_{8} \Delta \ln G D P_{t}+\varepsilon_{i t}
\end{gathered}
$$

With $\mathrm{Y}_{\text {it }}$ representing bank $\mathrm{i}$ credit growth and deposit growth at the time $\mathrm{t}$, Lerner is a measurement of competition and bank market power, while $\mathrm{CAR}_{\mathrm{it}-1}$ is the amount of bank i CAR ratio at the time of $\mathrm{t}-1$. Furthermore, Size is the size of the bank i at time t-1 which is the derivative of bank total assets, $\mathrm{EQ}_{\mathrm{it}-1}$ represents the growth of bank i equity and LQ is the bank's liquidity ratio, while $\mathrm{Fee}_{\mathrm{it}-1}$ is the proportion of fee income of bank $\mathrm{i}$. In addition, there are two macroeconomic control variables namely inflation and real GDP growth to explain the influence of independent variables more clearly and robust. Moreover, per Louati et al (2015) the analysis will be performed using lag (1) for the bank capital structure variable (CAR, size, liquidity ratio, and fee income) because the bank's behavior at time $t$ will be affected by the variable at time $t-1$. The use of lag (1) aims to produce more robust analysis and more clearly in describing the role of variables in influencing the behavior of bank in channeling and collecting funds.

\section{2. $\quad$ Measuring Lerner Index}

According to Ariss (2010) and Anginer (2014), to be able to measure the size of Lerner index, we previously required a bank marginal cost that can be measured using the trans $\log$ cost function below

$$
\begin{aligned}
\ln \left(C_{i t}\right)= & \alpha+\beta_{1} \ln \left(Q_{i t}\right)+\beta_{2} \ln \left(Q_{i t}\right)^{2}+\beta_{3} \ln W_{1_{i t}}+\beta_{4} \ln W_{2_{i t}}+ \\
& \beta_{5} \ln W_{3_{i t}}+\beta_{6} \ln Q_{i t} \ln W_{1_{i t}}+\beta_{7} \ln Q_{i t} \ln W_{2 i t}+\beta_{8} \ln Q_{i t} \ln W_{3_{i t}}+ \\
& \beta_{9} \ln \left(W_{1_{i t}}\right)^{2}+\beta_{10} \ln \left(W_{2_{i t}}\right)^{2}+\beta_{11} \ln \left(W_{3_{i t}}\right)^{2}+\beta_{12} \ln W_{1_{i t}} \ln W_{2_{i t}}+ \\
& \beta_{13} \ln W_{1_{i t}} \ln W_{3_{i t}}+\beta_{14} \ln W_{2_{i t}} \ln W_{3 i}+\varepsilon_{i t}
\end{aligned}
$$


Where $\mathrm{W}$ is a bank input cost consisting of $\mathrm{W}_{1}$ cost of labor; $\mathrm{W}_{2}$ cost of fund; and $\mathrm{W}_{3}$ cost of fixed capital. While $Q_{i t}$ is bank $i$ output quantity at the time $t$, and $C_{i t}$ is total cost incurred at bank $i$ at the time $t$. from the above regression estimation we will be obtained the coefficient required to calculate the marginal cost of all bank using equation 3 below.

$$
M C=\frac{C_{i t}}{Q_{i t}}\left(\beta_{1}+2 \beta_{2} \ln Q_{i t}+\beta_{6} \ln W_{1_{i t}}+\beta_{7} \ln W_{2_{i t}}+\beta_{8} \ln W_{3_{i t}}\right)
$$

After the marginal cost have known, the MC value will be used to calculate Lerner index by using the formula below

$$
\text { Lerner }_{i t}=\frac{P_{i t}-M C_{i t}}{P_{i t}}
$$

Where $\mathrm{P}_{\mathrm{it}}$ is price of total assets of bank $\mathrm{i}$ at thetime $\mathrm{t}$.

After the Lerner index value is known, following Louati et al. (2015) and Tabak et al. (2012) in order to produce more clearer and robust results in describing the role of banking competition in bank behavior in collecting and distributing funds, the Lerner index value will be divided into three dummy variables illustrates three levels of market power (1) High: Mean Lerner + $0.5 \sigma$ Lerner; (2) Low: Mean Lerner - $0.5 \sigma$ Lerner; (3) Average: Mean Lerner - $0.5 \sigma$ Lerner $\leq$ Average $\leq$ Mean Lerner $+0.5 \sigma$ Lerner. After dividing bank Lerner index into 3 separate group, we will be conducting four separate regression test that aims to describe the influence of independent variables that affect the dependent variable on the group of banks on certain group of market power. The result of the regression will give a better picture in doing the analysis and comparison because dividing bank sample into three group will allow a result of bank behavior analysis within similar characteristics and capital structures group of banks.

\begin{tabular}{|c|c|c|}
\hline $\begin{array}{l}\text { Dependent } \\
\text { Variable }\end{array}$ & Description & Symbol \\
\hline $\begin{array}{l}\Delta \text { Financing } \\
\Delta \text { Deposit }\end{array}$ & $\begin{array}{l}\text { Credit/ Financing growth of Bank } \mathrm{i} \text { at the time } \mathrm{t} \\
\text { Deposit growth of Bank } \mathrm{i} \text { at the time } \mathrm{t}\end{array}$ & Yit \\
\hline $\begin{array}{l}\text { Independent } \\
\text { Variable }\end{array}$ & Description & Symbol \\
\hline $\begin{array}{l}\text { Market Power } \\
\text { CAR }\end{array}$ & $\begin{array}{l}\text { Bank i market power at the time } t \text { (Lerner index) } \\
\text { Bank i capital adequacy ratio at the time } t\end{array}$ & $\begin{array}{l}\text { Lernerit } \\
\text { CARit }\end{array}$ \\
\hline Control Variable & Description & Symbol \\
\hline $\begin{array}{l}\text { Size } \\
\Delta \text { Equity } \\
\text { Likuiditas } \\
\text { Fee Income } \\
\text { GDP Growth riil } \\
\text { Inflation }\end{array}$ & $\begin{array}{l}\text { Bank Size at the time } t-1 \\
\text { Equity Growth at the time of } t-1 \\
\text { Ratio of liquidity bank } i \text { at the time } t-1 \text { Income } \\
\text { from non-interest activity bank i at the time } t-1 \\
\text { Real GDP growth at the time of } t \\
\text { Inflation rate of Indonesia at the time of } t\end{array}$ & $\begin{array}{l}\text { Sizeit } \\
\text { EQit } \\
\text { LQit } \\
\text { Feeit } \\
\text { GDP } \\
\text { Inflation }\end{array}$ \\
\hline
\end{tabular}

Table 1. Operationalization of variables 


\section{Results and Discussion}

\subsection{Descriptive Statistics}

Descriptive statistics provide an overview of the behavior of all variables in this research that includes mean, median, maximum, minimum, and standard deviation. Below is presented descriptive statistics summarized in the form of tables 2 below.

Furthermore, in table 3 below presented descriptive statistics from the calculation of Lerner index of commercial banks based on the types of bank in the period of 2011-2015. In table 3 below we can note that despite shari'ah bank has a higher Lerner Index overall compared to conventional banks, but we can see that UUS dominated the average value which mean UUS has a much larger market power compared to BUS. That can be explained by the fact that UUS still has the support of capital and assets from its parent bank so UUS is much more well equipped to penetrate market and doesn't require huge number of total assets. The asset support allows UUS to reduce its operational costs for example by using the same ATM network with its parent bank. As we know, the value of the Lerner index determined by the company ability to set prices and determined by the company marginal cost. Lower MC by UUS means that UUS will have much higher Lerner index compared to others. Furthermore, from the table 3 we can conclude that the banking market in Indonesia is a monopolistic market. This is due to the nature of the market with a mixture of perfectly competitive market and monopolies, where there are some companies that dominate the market.

Table 2. Descriptive Statistics

Conventional Bank

\begin{tabular}{ccccccccc}
\hline & $\Delta$ Dep & $\Delta$ Loa & Lerner & CAR & SIZE & $\Delta$ Eqt & Liquidity & Fee Income \\
\hline Mean & 0.28 & 0.29 & 0.24 & 0.23 & 16.10 & 0.27 & 0.31 & 0.44 \\
Median & 0.15 & 0.19 & 0.22 & 0.18 & 15.92 & 0.12 & 0.28 & 0.23 \\
Maximum & 12.89 & 9.75 & 0.85 & 1.81 & 20.56 & 4.52 & 0.70 & 6.33 \\
Minimum & -0.45 & -0.41 & -0.56 & 0.00 & 11.98 & -0.26 & 0.11 & 0.01 \\
Std. Dev. & 0.82 & 0.63 & 0.20 & 0.20 & 1.93 & 0.48 & 0.10 & 0.66 \\
Sharia Bank & & & & & & & & \\
\hline & $\Delta$ Dep & $\Delta$ Fin & Lerner & CAR & SIZE & $\Delta$ Eqt & Liquidity & Fee Income \\
\hline Mean & 0.51 & 0.58 & 0.32 & 0.21 & 15.47 & 0.36 & 0.25 & 0.28 \\
Median & 0.33 & 0.35 & 0.32 & 0.17 & 15.46 & 0.14 & 0.23 & 0.21 \\
Maximum & 4.02 & 6.72 & 0.80 & 0.87 & 18.07 & 11.61 & 0.64 & 2.13 \\
Minimum & -0.27 & -0.46 & -0.29 & 0.11 & 12.73 & -2.42 & 0.06 & 0.00 \\
Std. Dev. & 0.77 & 0.98 & 0.21 & 0.14 & 1.23 & 1.30 & 0.09 & 0.29
\end{tabular}

Table 3. Descriptive Statistics Lerner Index

\begin{tabular}{lrrrrr}
\hline Descriptive & \multicolumn{3}{c}{ Sharia Bank } & \multicolumn{2}{c}{ Conven tional Bank } \\
& \multicolumn{1}{c}{ All } & \multicolumn{1}{c}{ B US } & \multicolumn{1}{c}{ UUS } & \multicolumn{1}{c}{ Al l } & \multicolumn{1}{c}{ Top 10 } \\
\hline Mean & 0.32 & 0.28 & 0.40 & 0.24 & 0.41 \\
Median & 0.32 & 0.26 & 0.39 & 0.22 & 0.43 \\
Maximum & 0.80 & 0.77 & 0.80 & 0.85 & 0.57 \\
Minimum & -0.29 & -0.29 & 0.07 & -0.56 & 0.23 \\
Std. Dev. & 0.21 & 0.21 & 0.19 & 0.20 & 0.10 \\
Observations & 95 & 65 & 30 & 345 & 50
\end{tabular}




\subsection{Regression Result}

In Table 4, we present the results of our model. Based on table 4 below we can see that conventional banks have a positive significant result on the relationship between bank behavior and ban market power with $99 \%$ confidence level. Our results are slightly different from Louati et al (2015) which showed a negative significant result on the regression of market power influence on $\Delta$ Financing and $\Delta$ Deposit. The high market power describes the position of the bank in the economy, the higher the market power means the more dominant the position of the bank and therefore the real sector depends heavily on the bank. Because of this dependence, there is an inelastic demand for loan so that despite an increase on interest rate the demand for loan will not significantly changed. Meanwhile on shari'ah bank, Lerner index only have a significant effect on $\Delta$ Financing and not significant on growth of Deposit. Significant influence on the growth of Islamic bank financing is like conventional banks which shows high dependence on bank to get additional funds. In addition, the market power of shari'ah banks has no effect to the level of deposit collected by the bank. This suggests that in addition to the dependence of the people on banks, according to research by Louati et al (2015) that customers of shari'ah banks also have a religious motive in using the services of shari'ah banks, so the tendency of customers to make a saving account is not significantly affected by other variables.

Furthermore, the impact of CAR influence on bank behavior is analyzed. In this context, Mastura et al. (2014) suggest that capital requirements have a significant impact on the behavior of loans and deposits of 52 Islamic banks and 186 conventional banks belonging to 14 different countries over the period 1999-2009. Their results show that capitalization is positively related to the deposit and loan variations of both Islamic and conventional banking sectors. We can see from table 4 that our research support Mastura et al (2014) because CAR has a positive significant effect on conventional bank behavior, but only at $10 \%$ significance level on shari' ah bank. The increase in funds collected by bank will be affected by changes in the CAR ratio, this is because deposit is the main source of bank funding. In addition, a significant positive impact on funds distributed by banks suggest that bank in Indonesia follow supply theory which shows the bank's behavior in distributing loans and financing will be influenced by the level of bank capital.

Considering the dummy variable that divides the bank into separated groups based on the market power value, it can be seen that for conventional banks, the value of CAR will significantly affect negatively only on group of banks with low market power. Since bank in larger market power group usually has a CAR level well above the minimum requirement of $8 \%$ so CAR will not significantly affect the $\Delta$ Financing and $\Delta$ Deposit the bank. While on a smaller group of market power, Mastura et al (2014) argue that capital crunch hypothesis can explain the cause of the increased in CAR will cause the decreased on $\Delta$ Financing and $\Delta$ Deposit because bank must adjust the risk weighted assets its bear.

Besides banking market power and CAR ratios which are the main independent variables in this study, there are others determinant of $\Delta$ financing and $\Delta$ deposits that become a control variables in doing regression estimation. First, bank size both in shari'ah banks and conventional banks will significantly negatively affect bank behavior described by $\Delta$ financing and $\Delta$ deposit. This result is consistent with the research of Louati et al. (2015), and Mastura et al. (2014) which showed similar results. According to Mastura et al. (2014) the larger the size of a bank, the growth of its financing and deposit will most likely to slow down. Larger banks will allocate fewer assets in the form of credit loans and will instead allocate more to short-term investments that offers much better return with more risk. 
Table 4. Regression Model Estimation Result

\begin{tabular}{|c|c|c|c|c|c|c|c|c|c|c|c|c|c|c|c|c|}
\hline & \multicolumn{8}{|c|}{ Conventional Bank } & \multicolumn{8}{|c|}{ Islamic Bank } \\
\hline & \multicolumn{4}{|c|}{$\Delta$ Deposit } & \multicolumn{4}{|c|}{$\Delta$ Loan } & \multicolumn{4}{|c|}{$\Delta$ Deposit } & \multicolumn{4}{|c|}{$\Delta$ Financing } \\
\hline & All & High & Average & Low & All & High & Average & Low & All & High & Average & Low & All & High & Average & Low \\
\hline \multirow[t]{2}{*}{ Lerner } & $0.294^{* * *}$ & $0.303 * * *$ & $0.267^{* * *}$ & $0.223^{* * *}$ & $0.216^{* * *}$ & $0.264 * * *$ & $0.194 * * *$ & 0.077 & -0.014 & -0.187 & 0.165 & 0.151 & $0.543^{* * *}$ & $0.478^{* * *}$ & $0.574 * *$ & $0.555^{* *}$ \\
\hline & $(0.000)$ & $(0.001)$ & $(0.001)$ & $(0.000)$ & $(0.000)$ & $(0.000)$ & $(0.000)$ & $(0.243)$ & (0.929) & $(0.318)$ & $(0.392)$ & $(0.572)$ & $(0.003)$ & $(0.004)$ & $(0.023)$ & $(0.039)$ \\
\hline \multirow[t]{2}{*}{$\operatorname{Car}(-1)$} & $1.828^{* * *}$ & $1.824 * * *$ & $1.857^{* * *}$ & $1.871^{* * *}$ & $1.745^{* * *}$ & $1.742^{* * *}$ & $1.783^{* * *}$ & $1.883^{* * *}$ & $0.413^{*}$ & 0.150 & $0.524 * *$ & 0.407 & $1.842^{* * *}$ & $1.645^{* * *}$ & $1.889 * * *$ & $1.814^{* * *}$ \\
\hline & $(0.000)$ & $(0.000)$ & $(0.000)$ & $(0.000)$ & $(0.000)$ & $(0.000)$ & $(0.000)$ & $(0.000)$ & $(0.069)$ & $(0.512)$ & $(0.033)$ & $(0.111)$ & $(0.000)$ & $(0.002)$ & $(0.000)$ & $(0.000)$ \\
\hline \multirow[t]{2}{*}{ High comp*CAR } & & -0.057 & & & & $-0.161 * * *$ & & & & $1.683^{* * *}$ & & & & 1.033 & & \\
\hline & & $(0.780)$ & & & & $(0.008)$ & & & & $(0.000)$ & & & & $(0.104)$ & & \\
\hline \multirow[t]{2}{*}{ Average comp*CAR } & & & -0.182 & & & & 0.068 & & & & $-0.814 * * *$ & & & & -0.230 & \\
\hline & & & $(0.351)$ & & & & $(0.404)$ & & & & $(0.000)$ & & & & $(0.392)$ & \\
\hline \multirow[t]{2}{*}{ Low comp*CAR } & & & & $-0.437 * * *$ & & & & $-0.549 * * *$ & & & & $0.363^{*}$ & & & & 0.134 \\
\hline & & & & $(0.001)$ & & & & $(0.007)$ & & & & $(0.096)$ & & & & $(0.615)$ \\
\hline \multirow[t]{2}{*}{ Size(-1) } & $-0.277^{* * *}$ & $-0.282 * * *$ & $-0.257^{* * *}$ & $-0.297^{* * *}$ & $-0.157^{* *}$ & $-0.173 * *$ & $-0.144^{*}$ & -0.130 & $-0.535^{* * *}$ & $-0.519 * * *$ & $-0.493^{* * *}$ & $-0.540 * * *$ & $-0.712 * * *$ & $-0.744 * * *$ & $-0.725^{* * *}$ & $-0.729 * * *$ \\
\hline & $(0.000)$ & $(0.000)$ & $(0.000)$ & $(0.000)$ & $(0.033)$ & $(0.014)$ & $(0.091)$ & $(0.110)$ & $(0.000)$ & $(0.000)$ & $(0.000)$ & $(0.000)$ & $(0.000)$ & $(0.000)$ & $(0.000)$ & $(0.000)$ \\
\hline \multirow[t]{2}{*}{$\Delta$ Equity } & $0.169^{* * *}$ & $0.167^{* * *}$ & $0.179 * * *$ & $0.194 * * *$ & $0.210 * * *$ & $0.206^{* * *}$ & $0.204^{* * *}$ & $0.252 * * *$ & -0.002 & 0.006 & 0.052 & -0.006 & -0.014 & -0.023 & -0.004 & -0.012 \\
\hline & $(0.000)$ & $(0.000)$ & $(0.000)$ & $(0.000)$ & $(0.000)$ & $(0.000)$ & $(0.000)$ & $(0.000)$ & $(0.969)$ & $(0.915)$ & $(0.425)$ & $(0.930)$ & $(0.807)$ & $(0.691)$ & $(0.938)$ & $(0.835)$ \\
\hline \multirow[t]{2}{*}{ Liquidity(-1) } & $-0.277^{* *}$ & $-0.332 * *$ & $-0.272^{* *}$ & $-0.221 * * *$ & $-1.427^{* * *}$ & $-1.421 * * *$ & $-1.465 * * *$ & $-1.274 * * *$ & $-1.175^{* * *}$ & $-1.625^{* * *}$ & $-1.254^{* * *}$ & $-1.129 * *$ & 0.566 & 0.219 & 0.505 & 0.560 \\
\hline & $(0.018)$ & $(0.012)$ & $(0.028)$ & $(0.002)$ & $(0.000)$ & $(0.000)$ & $(0.000)$ & $(0.000)$ & $(0.005)$ & $(0.000)$ & $(0.008)$ & $(0.011)$ & $(0.219)$ & $(0.636)$ & $(0.239)$ & $(0.201)$ \\
\hline \multirow[t]{2}{*}{ Fee Income(-1) } & 0.006 & -0.002 & 0.004 & $0.008^{* *}$ & $0.031^{* * *}$ & $0.034^{* * *}$ & $0.025^{* * *}$ & $0.031^{* * *}$ & 0.110 & $0.297^{*}$ & 0.110 & 0.111 & $0.454 * *$ & $0.539 * *$ & $0.440^{* *}$ & $0.452^{* *}$ \\
\hline & $(0.443)$ & $(0.834)$ & $(0.682)$ & $(0.047)$ & $(0.000)$ & $(0.000)$ & $(0.000)$ & $(0.001)$ & $(0.444)$ & $(0.098)$ & $(0.633)$ & $(0.529)$ & $(0.026)$ & $(0.018)$ & $(0.019)$ & $(0.016)$ \\
\hline \multirow[t]{2}{*}{ Inflation } & $0.534^{* * *}$ & 0.520 & $0.555^{* * *}$ & $0.547^{* *}$ & 0.196 & 0.222 & 0.086 & 0.131 & 0.292 & -0.467 & -0.133 & 0.267 & $1.491^{* *}$ & $1.233^{*}$ & $1.375^{* *}$ & 1.408 \\
\hline & $(0.005)$ & $(0.104)$ & $(0.001)$ & $(0.025)$ & $(0.232)$ & $(0.287)$ & $(0.653)$ & $(0.444)$ & $(0.642)$ & $(0.331)$ & $(0.809)$ & $(0.599)$ & $(0.011)$ & $(0.064)$ & $(0.042)$ & $(0.048)$ \\
\hline \multirow[t]{2}{*}{ GDP } & $-4.748^{* *}$ & $-4.755^{* *}$ & $-4.030 * * *$ & $-6.258^{* * *}$ & 4.196 & 3.612 & 4.651 & 4.642 & -0.383 & -0.803 & 1.973 & -1.501 & $-29.183^{* * 2}$ & $-32.185 *$ & $"-30.419 * *$ & $-29.996^{* * *}$ \\
\hline & $(0.011)$ & $(0.027)$ & $(0.003)$ & $(0.008)$ & $(0.201)$ & $(0.261)$ & $(0.223)$ & $(0.190)$ & $(0.968)$ & $(0.918)$ & $(0.832)$ & $(0.864)$ & $(0.000)$ & $(0.000)$ & $(0.001)$ & $(0.000)$ \\
\hline \multirow[t]{2}{*}{ Constant } & $4.140 * * *$ & $4.196 * * *$ & $3.799 * * *$ & $4.616^{* * *}$ & 1.021 & 1.295 & 0.759 & 0.708 & $8.827^{* * *}$ & $8.736^{* * *}$ & $8.094^{* * *}$ & $8.886^{* * *}$ & $11.969 * * *$ & $12.716^{* * *}$ & * $12.264 * * *$ & $12.284^{* * *}$ \\
\hline & $(0.000)$ & $(0.000)$ & $(0.000)$ & $(0.000)$ & $(0.492)$ & $(0.361)$ & $(0.652)$ & $(0.651)$ & $(0.000)$ & $(0.000)$ & $(0.000)$ & $(0.000)$ & $(0.000)$ & $(0.000)$ & $(0.000)$ & $(0.000)$ \\
\hline \multirow[t]{2}{*}{ F-stat } & 6.32 & 6.237 & 6.473 & 6.087 & 15.731 & 15.506 & 17.234 & 17.022 & 6.835 & 6.858 & 5.999 & 5.841 & 11.517 & 10.045 & 10.601 & 11.776 \\
\hline & 0.642 & 0.643 & 0.651 & 0.637 & 0.817 & 0.817 & 0.833 & 0.831 & 0.723 & 0.734 & 0.707 & 0.702 & 0.815 & 0.802 & 0.810 & 0.826 \\
\hline adjusted & 0.54 & 0.54 & 0.551 & 0.532 & 0.765 & 0.765 & 0.784 & 0.782 & 0.617 & 0.627 & 0.589 & 0.582 & 0.744 & 0.722 & 0.734 & 0.756 \\
\hline
\end{tabular}


Furthermore, based on the regression results above the growth of bank capital will significantly have a positive impact on variable $\Delta$ financing and $\Delta$ deposit on conventional bank. It is normal since most bank capital comes from deposits, so that increased capital will be accompanied by increase in savings. As for financing, it shows that more capital available will encourage bank to provide more credit and financing. In addition, as depicted in Table 4, Islamic banks and conventional banks have negative coefficients on the relationship between liquidity ratio and $\Delta$ Deposit which indicates that commercial banks in Indonesia will choose liquid assets compared to liabilities (deposit) as the majority of their capital. The increasing bank liquidity can be caused by the decline of deposit or bank liabilities growth. Fee income has a positively significant result on $\Delta$ financing both in conventional banks and shari'ah banks, while on $\Delta$ deposit showed insignificant results. These results indicate that commercial banks in Indonesia still prefer the income derived from financing activities. When the ratio of fee income increases, banks tend to immediately channel more funds on credit markets described in increased $\Delta$ financing when fee income increases and will decrease if otherwise.

Meanwhile, the macroeconomic variables show mixed results. For the inflation rate in shari'ah banks, $\Delta$ financing shows a significantly positive result which can be interpreted as shari'ah bank with its PLS scheme assume increase on inflation rate as growth of demand in real sector, so that shari'ah bank will increase investment and further increase growth of financing. While in conventional bank, significantly positive result on $\Delta$ deposit shows that banks have anticipated inflation and adjust the price so that fixed interest attract customers to make deposits at conventional banks. In general, all models show positive coefficients that match the allegation that the higher the value of money then $\Delta$ financing and $\Delta$ deposit will also grow.

\section{Conclusion}

After conducting a series of analyzes, this research found that Islamic banks have a relatively higher rate of market power compared to conventional banks. This is caused by the higher market power in the UUS due to the low marginal cost UUS have. Overall, the largest conventional bank dominates the market indicates that the banking market in Indonesia is monopolistic. In addition, both shari'ah and conventional banks have a CAR value that are well above the recommended value set by OJK (12\%). This indicates that in general, the level of capital strength of shari'ah banks and conventional banks in Indonesia are in a healthy condition.

Overall, this research indicates that the banking industry in Indonesia will be more effective in carrying out its intermediary function in the market with a few bank members but large in size so that the bank is able maintain a high market power. This is illustrated by the value $\Delta$ financing and $\Delta$ deposit which has a significant positive coefficient with Lerner index value. While the larger the size of banks will offer a good capital structure and a high CAR level. The higher the CAR value will make the bank has a good level of bank soundness and gain more public trust to operate effectively fulfill its role as an intermediary institution.

\section{References}

Abduh, M., \& Azmi Omar, M. (2012). Islamic banking and economic growth: the Indonesian experience. International Journal of Islamic and Middle Eastern Finance and Management, 5(1), 35-47. 
Allen, F., \& Gale, D. (2004). Competition and financial stability. Journal of Money, Credit and Banking, 36(3), 453e480.

Anginer, D., Demirguc-Kunt, A., \& Zhu, M. (2014). How does deposit insurance affect bank risk? Evidence from the recent crisis. Journal of Banking \& finance, 48, 312-321.

Antonio, M. S. I. (2001). Bank Syariah: Dari Teori ke Praktik. Gema Insani.

Ariss, R. T. (2010). Competitive conditions in Islamic and conventional banking: A global perspective. Review of Financial Economics, 19(3), 101-108.

Ayub, M. (2007). Understanding Islamic Finance: AZ Keuangan Syariah. PT Gramedia Pustaka Utama.

Chattha, Jamshaid Anwar (2015). "Significance and Key Challenges in Conducting Stress Testing for Islamic Commercial Banks." Global Review of Islamic Economics and Business 1.2: 085-098.

Chong, S., \& Liu, M. (2009). Islamic Banking: Interest-free or interest-based ?. Pacific-Basin Finance Journal, 17(1), 125-144.

Church, J. R., \& Ware, R. (2000). Industrial organization: a strategic approach.Singapore:Mcgraw -hill

Louati, S., Gargouri, I., \& Boujelbene, Y. (2015). Capital adequacy implications on Islamic and non-Islamic bank's Behavior : Does market power matter? Borsa Istanbul Review, 15(3), 192-204.

Mastura, A. K., Kabir, H., Taufiq, H., \& Shamsher, M. (2014). Capital adequacy and lending and deposit behaviors of conventional and Islamic banks. Pacific-Basin Finance Journal, 28, $58 \mathrm{e} 75$.

Matutes, C., \& Vives, X. (2000). Imperfect competition, risk taking, and regulation in banking, 44, 1-34

Pepall, Lynne, Daniel Jay Richards, and George Norman (2005). Industrial organization. Ed. Pal Debashis. Thomson/South-Western.

Repullo, R. (2004). Capital requirements, market power, and risk-taking in banking. Journal of financial Intermediation, 13(2), 156-182.

Suarez, J. (1994). Closure rules, market power and risk-taking in a dynamic model of bank behaviour (pp. 123-172). LSE Financial markets group.

Weill, L. (2011). Do Islamic banks have greater market power? Comparative Economic Studies, 53(2), 291-306.

Yeyati, E. L., \& Micco, A. (2007). Concentration and foreign penetration in Latin American banking sectors: Impact on competition and risk. Journal of Banking \& Finance, 31(6), 1633-1647. 